\title{
Usage of a Non-Destructive Testing Technology for Assessment of Porosity in Aluminium Casts Alloys
}

\author{
Lenka Kuchariková1, Eva Tillová1, Michaela Kritikos ${ }^{2}$, Milan Uhríčik ${ }^{1}$, Ivana Švecová ${ }^{1}$ \\ ${ }^{1}$ Faculty of Mechanical Engineering, University of Žilina. Univerzitná 8215/1, 01026 Žilina. Slovak Republic. E- \\ mail: lenka.kucharikova@fstroj.uniza.sk, eva.tillova@fstroj.uniza.sk, ivana.svecova@fstroj.uniza.sk, \\ ${ }^{2}$ Materials Fabrications Laboratory Advanced Technologies Research Institute, Faculty of Materials Science and \\ Technology in Trnava, Slovak University of Technology in Bratislava. Jána Bottu 2781/25, 91724 Trnava, Slovak \\ Republic.E-mail: michaela.kritikos@stuba.sk
}

The assessment of porosity in aluminium casting is the main object to reach the required properties. The determination of amount, size, 3D morphology of casting defect by using a non-destructive (ND) method, especially the computed tomography (CT), is important for assessment casting with complex internal areas that could not be inspected by conventional measurements without failure of the final products. The aim of this study is assessment of bars casted by gravity die casting in to the sand moulds with using the computed tomography. The size, amount and volume of casting defect were assessment by equipment Zeiss Metrotom and software Metrotom OS and VG studio MAX. The results show the influence of the shape of the moulds on the quality of the bars and thus the size, amount and volume of casting defects.

Keywords: X-ray computed tomography, non-destructive testing, porosity, metrology, secondary aluminium alloys,

\section{Introduction}

The casting components quality is traditionally controlled first with using 3D coordinate measuring machines. The control department must declarant if the product meets the quality requirements. The dimension control with such equipment is no so easy needs to cut the components and needs a lot of time [1-3]. The time is very important in foundry companies in order to no product the scrap products. Therefore, the computed tomography belongs to the new possibilities in measurements of components parts which could not be evaluated by conventional measuring methods without cutting the components and needs a lower time. This method offers rating options in different sides and uses X-rays to obtain 2D images taken around an axis of rotation and digital processing to generate a 3D image of the inside of an object from the $2 \mathrm{D}$ images. The $3 \mathrm{D}$ reconstruction of the structure can be converted into input data for subsequent numerical analyses using proper software [4-10].

The first measurements with using existing CT scanners were around the 1991, but accuracy was not better than about $0.1 \mathrm{~mm}$. The changes for better using of CT equipment were in year 2005. The major application of CT scanners is for medical imaging and for material analysis (especially assessment of inner structure of materials - positions and size of cast defects, fracture mechanics, damage modelling, etc.) [410]. The great opportunity for CT is possibilities of control of workpieces having no accessible internal features (e.g. components produced by additive manufacturing) or multi-material components (e.g. $2 \mathrm{~K}$ injection moulded plastic parts or plastic parts with metallic inserts) [7-8]. The CT methods are also used as a fully automated inspection method of throughput requirement (10 seconds for smaller piston or suspension parts up to 80-90 second for a complex engine part e.g. cylinder head.) including the entire acquisition and analysis of data [6]. Also can be used for optimization of casting process [9]. These non-contact measuring technique, it also might become a competitor to other novel noncontact quality inspection methods, like fringe projection, laser scanners, the tightness test, ultrasonic testing or the eddy current technique etc. [7,11]. The CT analysis have also limits as: practical limits imposed by the size and alloy of the casting, the time needed to conduct a CT scan, and the risk/reward calculus of the casting's commercial value, the system considers as pore any defects that has a lower density that the tested material and as inclusion any defects that has a higher density that the tested material, the size of products, they are very expensive and cannot distinguish touching grains of the same mineral nor can they clearly separate different minerals with very similar properties, etc. [12-14].

The second major problem which needs to be controlled for declarant if the product meets the quality requirements are casting defects. The porosity in cast- 
ings is one of the basic problem, because has considerable influence on fatigue properties and can be considered as fatigue crack initiators. The porosity is higher in pressure die casting considering very turbulent flow of liquid metal in the mould cavity, therefore current aluminium automotive parts such as wheels, engine, transmissions components are produced by gravity die casting for control gas porosity. The porosity formation is caused mostly by: the purity of the metal, the design of the mould and cast parts (e.g. wall thickness, sharp corners in the mould), pressure and shot speed of the machines, the melt flow speed during the mould filling, thermal conductivity of the mould (as in sand, investment or plaster low moulds), too much lubricant in the die, low/too hot metal temperatures, dross in holding furnace, blocked pour hole, etc. [3, 15-18]. However, the detection of all cast defect (shrinkage, porosity, gas holes, hot tears, cracks, inclusions, cold shuts) is very difficult, therefore the ND technology have still increasing industrial interest [11,19]. The CT designed for metrology applications is the best chose for assessment casting products [1].

Based on these facts the computed tomography was used for assessment of formation of casts defect in aluminium alloys produced by gravity die casting in to the sand mould. The experiment was creating as cooperation UNIZA with foundry company Uneko Ltd. Zátor, Czech Republic and Materials fabrications laboratory advanced technologies research institute in Trnava, Slovak Republic.

\section{Experimental work}

However, the gravity die casting is especially used for gas porosity control and the casting into the sand mould offers producing the any size casts $[19,20]$, the experimental material was casted in to the sand mould (Fig. 1).

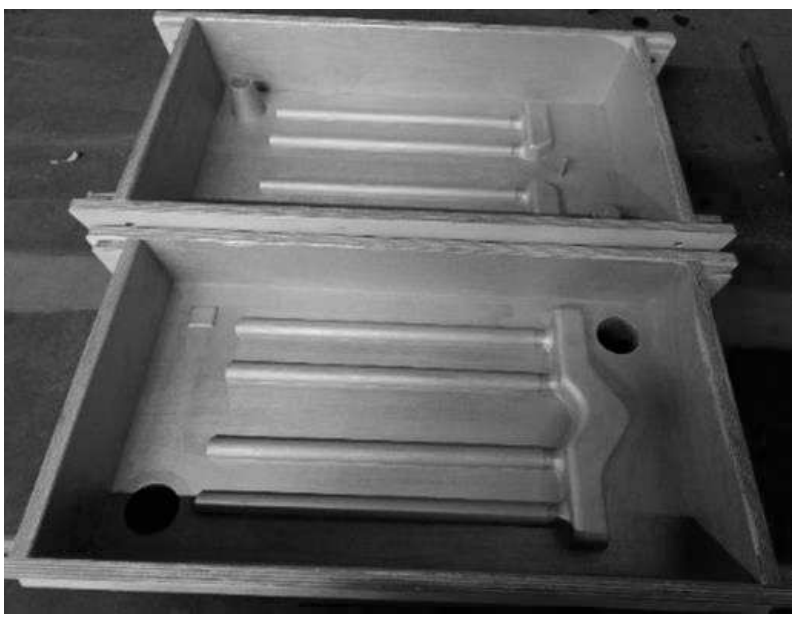

Fig. 1 The model of the mould for sand casting of the experimental bars

Casted were four bars with dimensions $300 \mathrm{~mm}$ length and diameter $20 \mathrm{~mm}$ once (Fig. 2a) from AlZn10Si8Mg cast alloys (Tab. 1).

Tab. 1 Chemical composition of AlZn10Si8Mg alloy according to delivery note (in wt. \%)

\begin{tabular}{|l|l|l|l|l|l|l|l|l|l|}
\hline $\mathbf{S i}$ & $\mathbf{Z n}$ & $\mathbf{F e}$ & $\mathbf{M g}$ & $\mathbf{C u}$ & $\mathbf{T i}$ & $\mathbf{N i}$ & $\mathbf{B i}$ & $\mathbf{S b}$ & $\mathbf{A l}$ \\
\hline 8.69 & 8.73 & 0.150 & 0.382 & 0.003 & 0.071 & 0.0379 & 0.003 & 0.0078 & balance \\
\hline
\end{tabular}

The experimental specimens (Fig. 2b) for assessment of porosity with non-destructive method were made with turning operation. From one bars were made two pieces of the specimens. Each specimen was marked with number of bars (Fig. 2a), positions in bars (Fig. 2b) and with direction of casting.

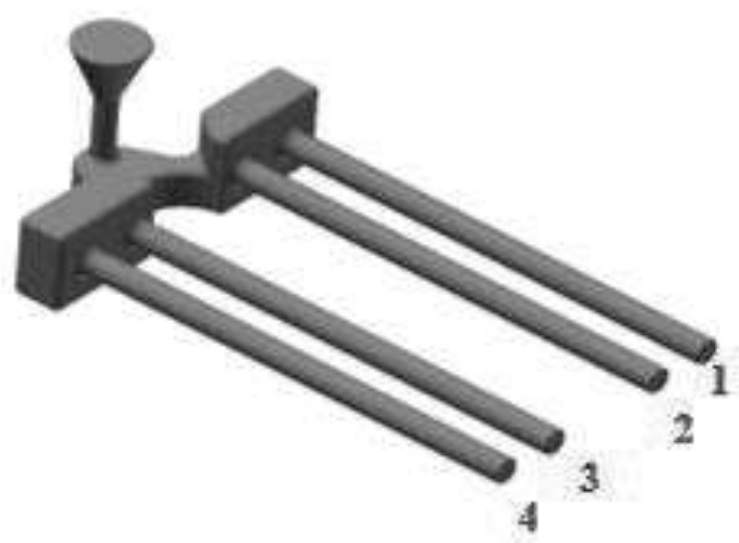

a) casted bars from experimental materials

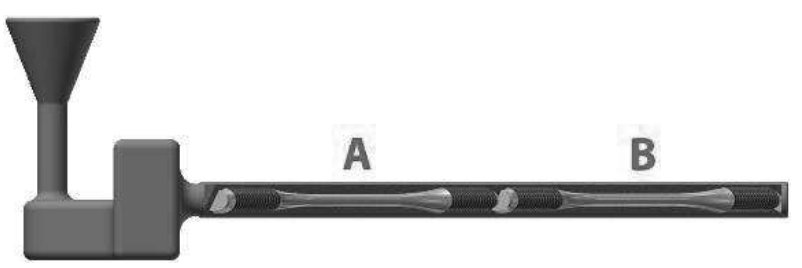

b) two pieces of the specimens for CT assessment

Fig. 2 The model of the experimental bars and specimens

The non-destructive testing of formation of the casting defects in experimental specimens was done with using computed tomography. The equipment METROTOM 1500 - X-ray from Zeiss company (Fig. 3) was used for these measurements. It is equipment for non-destructive testing of parts made of plastic, ceramics or composite materials, as well as magnesium, aluminium and steel with the resolution of 1024x1024 (half) and 2048x2048 pixels (full resolution). Scanning by full resolution is leading to half voxel size in comparison to scanning by half resolu- 
tion. The three tested specimens were evaluated together. The axis distance was: $\mathrm{X}=550, \mathrm{Y}=0,1753, \mathrm{Z}$ $=80$, the voltage $185 \mathrm{KW}$ and current $700 \mu \mathrm{A}$. The $\mathrm{Cu}=1 \mathrm{~mm}$ filter was used for ensuring the resolvability. The software METROTM OS was used for processing of scanned data and software VG Studio MAX for evaluation of the casting defects. Each measurement consisted of 30 images. The characteristics of casting defects were measured without limited in 2D measurements, but in 3D was set the minimum size of defects $0,15 \mathrm{~mm}^{3}$ according to standards at this measurement. The measurements in $2 \mathrm{D}$ were right in the middle of the samples in the longitudinal and transverse directions.

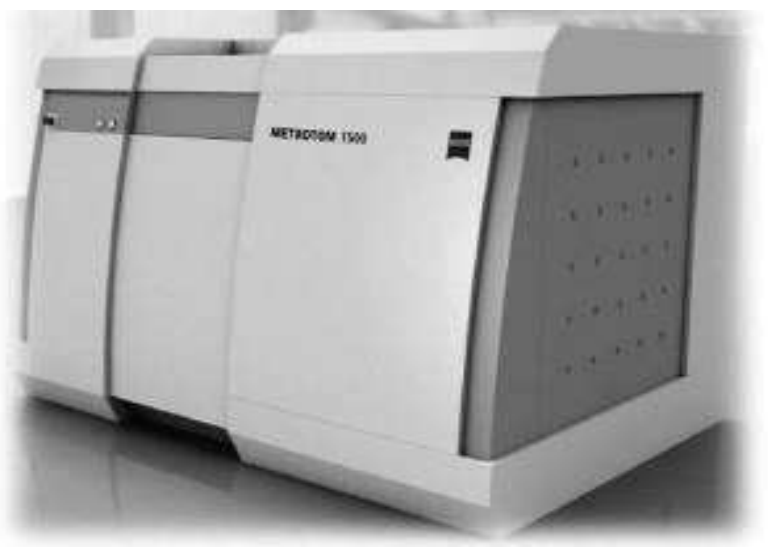

Fig. 3 The METROTOM 1500 - X-ray from Zeiss company [8]

The scanned data (size and dimensions of specimens) were compared with the CAD model. It is carried out to completely analyse form deviation and deformation of the part (with colours). Also, as was mentioned before [1-3], the dimension control is the first step of the casting components control. Since as the experimental samples were used specimens for mechanical test the differences were not recorded.

The mechanical testing specimens (Fig. 2b) were made according to the standards (ISO 6892-1:2009) for measuring the ultimate tensile strength (UTS), yield strength (YS) and ductility (A). Their changes were measured on INSTRON Model 5985 according to the standard ISO 6892-1:2009. Test rates and control are set according to Method A recommended range. Template is intended for specimens that produce a clearly defined linear elastic region and homogenous deformation. The calculated results include UTS, YS and A. The evaluated results represent average values of the six separate measurements.

\section{Results and discussions}

The working length purity is important in measurements of mechanical properties. Therefore, the main object was purity of the working length $(50 \mathrm{~mm})$ of specimen's controlled with using CT (Fig. 4). The working length was divided to the 10 same parts (5 $\mathrm{mm}$ ) in order to better evaluating the results of mechanical test and also for better identification and comparison the scanned data (position of casting defect) with real rupture (its position).

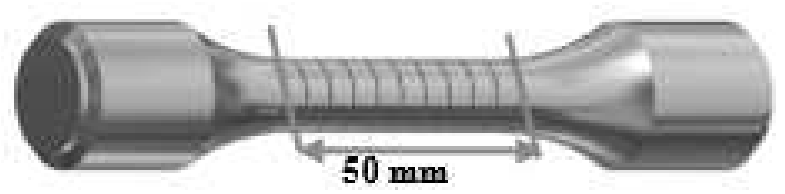

Fig. 4 Working length of testing specimens

\section{Direction of casting}

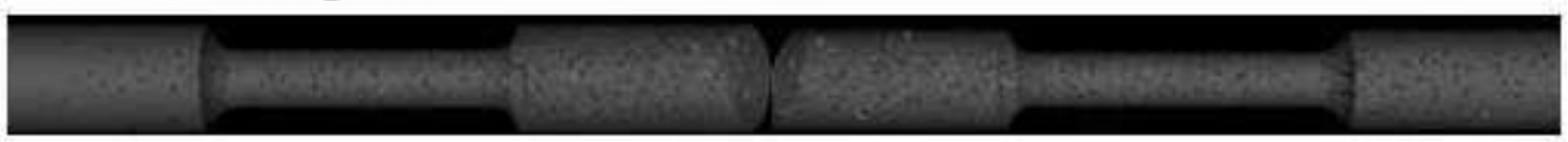

a) Specimens from bars marking 1

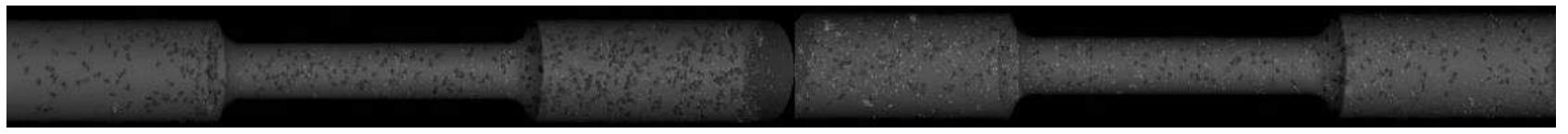

b) Specimens from bars marking 2

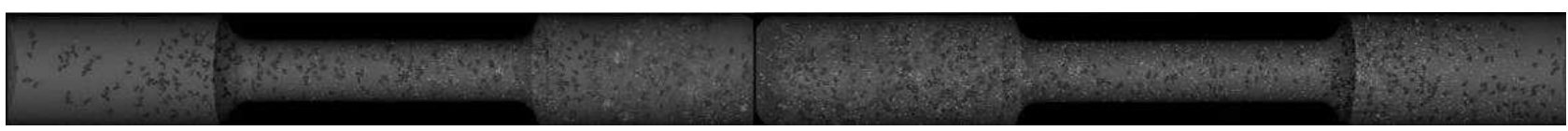

c) Specimens from bars marking 3

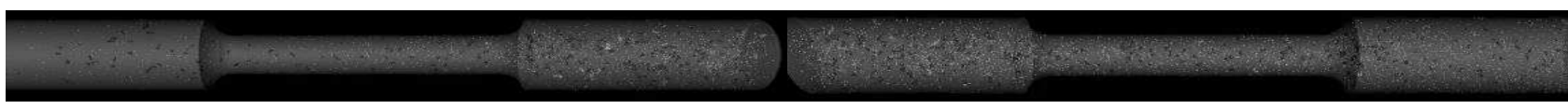

d) Specimens from bars marking 4

Fig. 5 Distribution of casting defect along the casted bars 


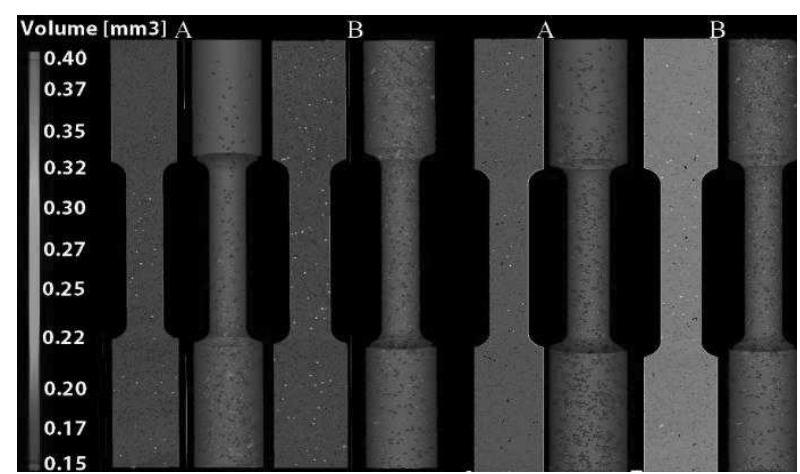

Specimens from bars marking Specimens from bars marking 1 2

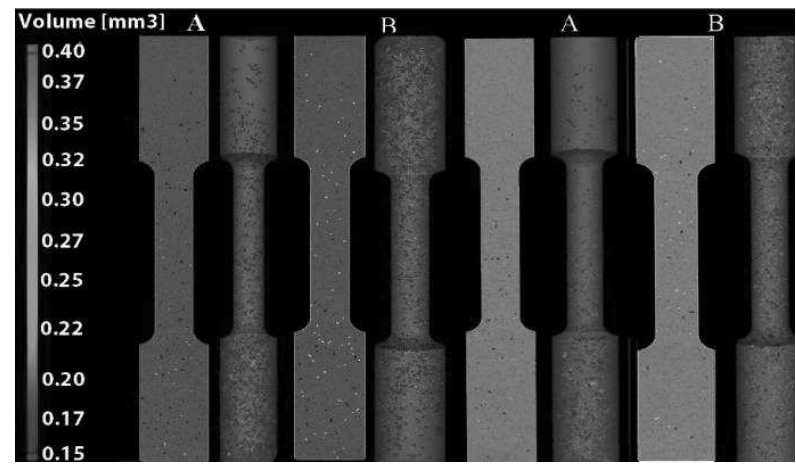

Specimens from bars marking Specimens from bars marking 3 4

Fig. 6The 2D and $3 D$ assessment of casting defect in specimens with using $C T$

The results of the computed tomography show changes in distributions of casting defects in experimental specimens along whole direction of the filling the mould (Fig. 5). The smallest amount of casting defects was observed at the beginning of the bars, in the middle is amount the highest and that again little de- crease (Fig. 5). These great changes in position of casting defects are most visible in bars 1 and 4 (Fig. 5).

The working length of each specimens is therefore affected with position of the specimens in bars and also with number of casted bars. The CT analysis confirmed that specimens marked A have smallest volume of the casting defects on the left sides from the middle of specimen, but the right side has a larger casting defect with increasing their ratio (Fig. 5), but also greater changes are better visible in bars 1 and 4 . The premise is that this distribution of the casting defect will have affect to rupture of the specimens - no in the middle but in the places with higher amount of the casting defect.

The statistical measurement by using computed tomography software shows that volume, volume ratio and number of identified casting defects (Tab. 2) are smaller in specimens marked as A comparison to specimens marked as B for each bars, too. The position of bars (Fig. 2a) seems to be important, because these characteristics increase in bars 2 and 3 (Tab. 2). The results (Table 2) of these defects characteristics are comparable for specimen's A and B from bars 1 and 4 , but bars 2 and 3 have about $50 \%$ increase. The CT analysis also confirmed that specimens with longer amount of defect have a larger proportion of smaller defects (up to size $0.17 \mathrm{~mm}^{3}$ ) comparison to specimens with smaller amount (Fig. 6). The specimens with smaller amount of defects have more defect up to the size around $0.37 \mathrm{~mm}^{3}$. From these results (Fig. 6 , Table. 2) it follows that the amount of defects is higher in bars in the middle of mould (closer to the inlet system), but the smallest value of characteristics has specimen A from bars 1 and the largest has specimen $\mathrm{B}$ from bars 3 .

Tab. 2The statistical results of casting defect volume characteristics

\begin{tabular}{|c|c|c|c|c|c|c|c|c|}
\hline $\begin{array}{c}\text { Specimens } \\
\text { Statistical results }\end{array}$ & \multicolumn{2}{c|}{ from bars 1 } & \multicolumn{2}{c|}{ from bars 2 } & \multicolumn{2}{c|}{ from bars 3 } & \multicolumn{2}{c|}{ from bars 4 } \\
\cline { 2 - 10 } & A & B & A & B & A & B & A & B \\
\hline Defect volume $\left[\mathrm{mm}^{3}\right]$ & 65.78 & 83.68 & 132.93 & 158.93 & 181.45 & 200.57 & 68.77 & 101.06 \\
\hline Defect volume ratio [\%] & 0.24 & 0.32 & 0.48 & 0.52 & 0.68 & 0.73 & 0.25 & 0.38 \\
\hline $\begin{array}{c}\text { Number of identified casts de- } \\
\text { fects }\end{array}$ & 322 & 407 & 587 & 642 & 793 & 860 & 364 & 528 \\
\hline
\end{tabular}

Tab. 3 The statistical results of each defects characteristics

\begin{tabular}{|c|c|c|c|c|c|c|c|c|c|c|c|c|c|}
\hline \multirow{2}{*}{\multicolumn{2}{|c|}{$\begin{array}{c}\text { Statistical } \\
\text { results }\end{array}$}} & \multicolumn{3}{|c|}{ Radius [mm] } & \multicolumn{3}{|c|}{ Diameter [mm] } & \multicolumn{3}{|c|}{ Surface $\left[\mathrm{mm}^{2}\right]$} & \multicolumn{3}{|c|}{ Volume $\left[\mathrm{mm}^{3}\right]$} \\
\hline & & min. & $\max$ & average & $\min$. & $\max$ & average & min. & $\max$. & average & $\min$. & max. & average \\
\hline \multirow{2}{*}{$\begin{array}{c}\text { from } \\
\text { bars } 1\end{array}$} & $\mathbf{A}$ & 0.50 & 1.34 & 0.719 & 0.99 & 2.67 & 1.433 & 2.58 & 14.58 & 4.334 & 0.15 & 0.64 & 0.202 \\
\hline & B & 0.46 & 1.21 & 0.721 & 0.92 & 2.42 & 1.438 & 2.44 & 10.67 & 4.253 & 0.15 & 0.57 & 0.205 \\
\hline \multirow{2}{*}{$\begin{array}{c}\text { from } \\
\text { bars } 2\end{array}$} & $\mathbf{A}$ & 0.50 & 1.18 & 0.718 & 1.0 & 2.36 & 1.437 & 2.71 & 8.91 & 4.142 & 0.15 & 0.40 & 0.192 \\
\hline & B & 0.48 & 1.42 & 0.773 & 0.96 & 2.84 & 1.546 & 2.51 & 15.05 & 4.843 & 0.15 & 0.72 & 0.226 \\
\hline \multirow{2}{*}{$\begin{array}{l}\text { from } \\
\text { bars } 3\end{array}$} & A & 0.44 & 1.68 & 0.750 & 0.87 & 3.37 & 1.501 & 2.44 & 31.35 & 4.665 & 0.15 & 2.35 & 0.229 \\
\hline & B & 0.46 & 1.48 & 0.736 & 0.92 & 2.96 & 1.473 & 2.3 & 20.06 & 4.511 & 0.15 & 0.96 & 0.233 \\
\hline \multirow{2}{*}{$\begin{array}{c}\text { from } \\
\text { bars } 4\end{array}$} & $\mathbf{A}$ & 0.49 & 1.20 & 0.711 & 0.99 & 2.40 & 1.417 & 2.66 & 9.96 & 4.005 & 0.15 & 0.44 & 0.188 \\
\hline & B & 0.45 & 1.23 & 0.683 & 0.89 & 2.46 & 1.362 & 2.43 & 8.58 & 3.832 & 0.15 & 0.54 & 0.191 \\
\hline
\end{tabular}




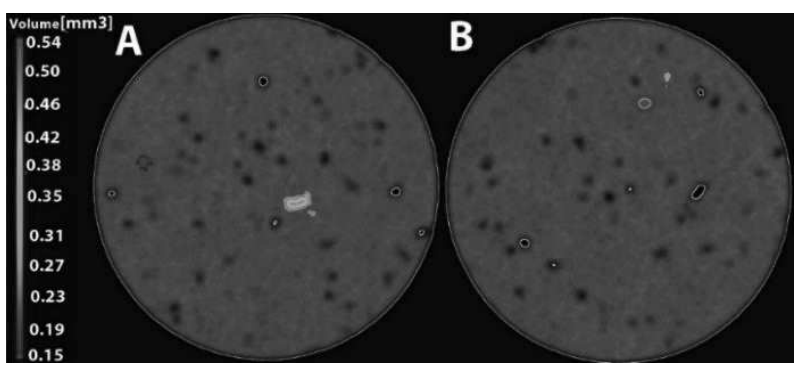

a) Specimens from bars marking 1

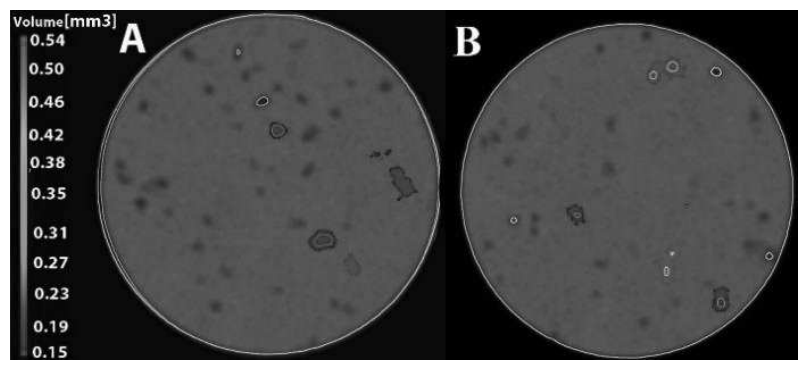

b) Specimens from bars marking 2

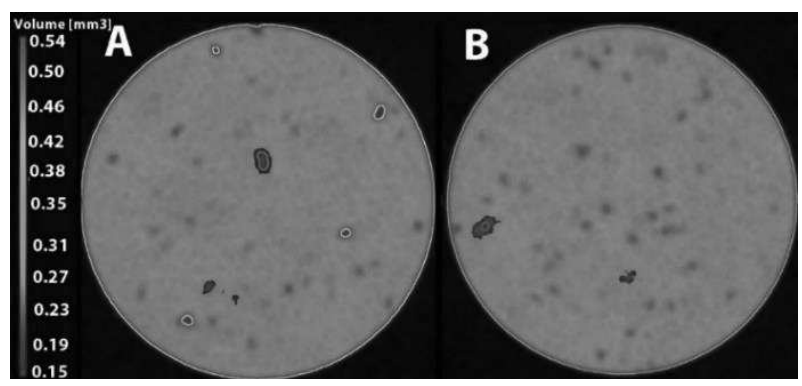

c) Specimens from bars marking 3

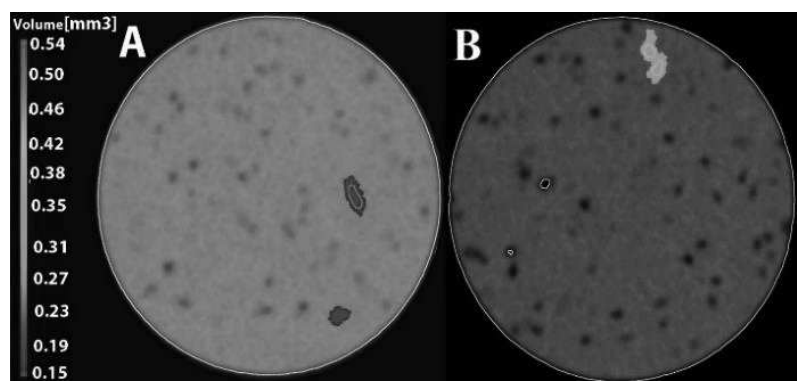

d) Specimens from bars marking 4

Fig. 7 The 2D assessment of porosity in transverse direction with using $C T$
The results of statistical measurements of each casting defects in experimental specimens shows Tab. 3. These average results (Table 3) are similar for each specimen. The specimens A from bars 1 and bars 4 have the smallest volume of defect in working length (Fig. 6), but it is not possible to claim that they have the lowest value of statistical results of each defects characteristics (Table 3). The lowest has specimen B from bars 4 and the highest has B from bars 2 and 3 . From these statistical results it can be assumed that mechanical properties of specimens from bars 2 will by decreasing comparison to specimens from bars 4 .

The casting defect formation in transverse direction was evaluated with CT analysis exactly in the middle of working length of specimens (Fig. 7). This position was chosen considering to optimal fracture at mechanical tests. The results show that specimens from each bars have different volume and size of casting defect in the middle of the specimens. From these results can be predicted that specimen's B from bars 4 will have the lowest properties in order to presence the large casting defect near to the edges of specimens. Also the specimens A and B from bars 2 have the higher amount of casting defect in the middle therefore could have the lower mechanical properties comparison to other specimens. The results of mechanical properties show that the position of the bars in casts is not so important, because specimens have comparable mechanical properties. The difference was observed only in position in bars as were mentioned above.

The specimens A from bars 1 and 4 have higher properties comparison specimens B from the same bars (Tab. 4). The bars with higher amount of casting defects (bars 2 and 3) have the opposite results. Specimens B have a higher properties such specimens A. The differences are only about $7 \%$ which is common mistakes of measurements according to standards. In general, however, it can be stated that specimens $\mathrm{A}$ from bars 4 have the highest properties, but the second part of this bars marked as $\mathrm{B}$ have the smallest properties with specimen A from bars 3 .

Tab. 4 The results of mechanical properties of experimental specimens

\begin{tabular}{|c|c|c|c|c|c|c|c|c|}
\hline $\begin{array}{c}\text { Specimens } \\
\text { results }\end{array}$ & \multicolumn{2}{|c|}{ from bars 1 } & \multicolumn{2}{c|}{ from bars 2 } & \multicolumn{2}{c|}{ from bars 3 } & \multicolumn{2}{c|}{ from bars 4 } \\
\cline { 2 - 8 } & A & B & A & B & A & B & A & B \\
\hline UTS [MPa] & 153.41 & 134.95 & 148.61 & 154.22 & 132.26 & 141.85 & 156.12 & 139.54 \\
\hline A [\%] & 1.50 & 1.66 & 1.5 & 1.65 & 1.68 & 1.18 & 1.69 & 2.13 \\
\hline YS [MPa] & 109.91 & 85.92 & 110.58 & 110.90 & 83.26 & 108.9 & 111.62 & 81.74 \\
\hline
\end{tabular}

After mechanical test were examined the places where the specimens were destroyed (Fig. 8). The analysis shows that rupture of specimens was not still around the middle of specimens. The CT analysis demonstrated that positions of rupture of specimens were affected with highest volume of the casting defects (Fig. 8). The specimens with presence the casting defects along whole working length were broken in the middle or near the middle (Fig. 8a). The specimens with smaller amount of casting defect on the left side of working length, were broken on the right side (Fig. $8 \mathrm{~b})$. These are places with higher amount of casting defect. 

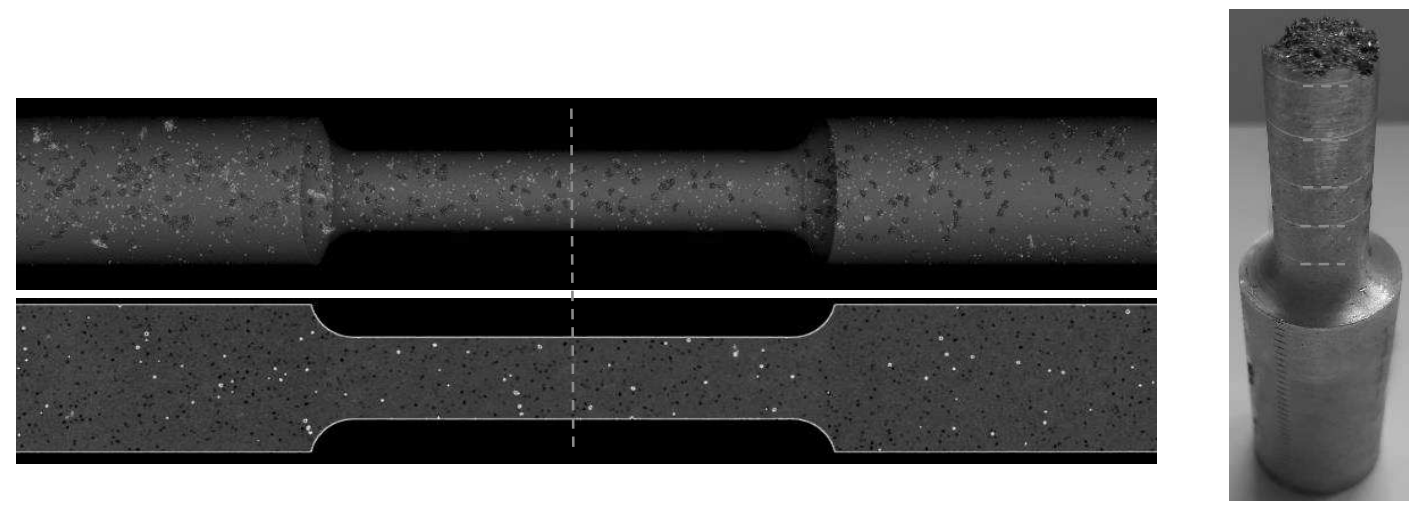

a) In the middle / near the middle
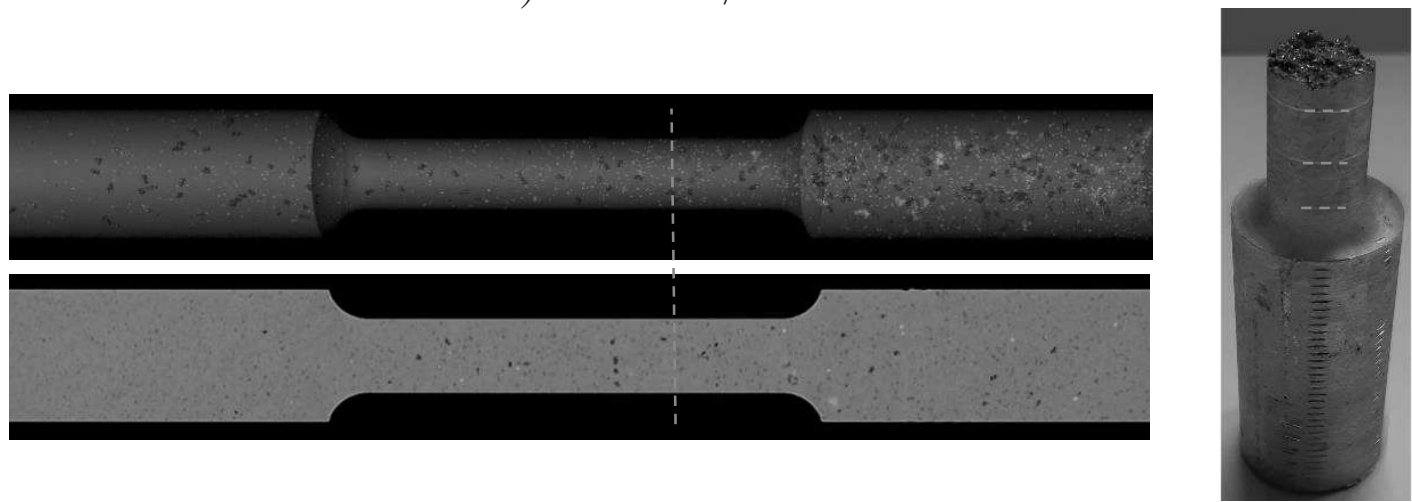

b) In the places with higher volume of cast defects / defects on the surfaces

Fig. 8 Places of the rupture of the specimens

\section{Conclusions}

This study confirms that CT - X-ray analysis is a good tool for studying the casting defects in general. It is a non-destructive and quick method that reliably illustrates the occurrence of mistakes in the investigated structure and provides information about their classification in the material volume. The opportunity is also possibilities to comparing the scanned samples with CAD model. It offers knowledge about deviation and deformation of the casted samples.

Very important are the results of casting defects volume in components, because lead to decreasing the mechanical properties as shows the results of this study. The CT analysis is comparable method with other additional measurements such as quantitative assessment on optical microscope or scanning electron microscopy, but these methods are destructive and needs a lot of times for reaching the results for foundry company.

\section{Acknowledgement}

This work has been supported by the grant projects $N^{o} 016 \check{Z} U-4 / 2020, N^{o} 1 / 0398 / 19, N^{o} 012 \check{Z} U$ -
4/2019. The authors also thank for cooperation with casting samples to Uneko Ltd. Company.

\section{References}

[1] TURriNI, N., VOLTAZZA, E., SIMON, M., SCHADEK, S. (2012). First Article Inspection of Aluminium Castings by Computed Tomography. 4th Conference on Industrial Computed Tomography (iCT), 19-21 September 2012, Wels, Austria (iCT 2012), NDT.net, Vol.12.

[2] PARIDA, N. (1999). Non-destructive testing and evaluation of cast materials. In: Materials characterisation techniques - principles and applications. (Editors: Sridhar G., Showdhury G. S., Goswami N.G.) pp. 177-193.

[3] PRÍSTAVKA, M., KOLOMAN, K. (2018). Evaluation of quality costs in the production organization. In: Manufacturing technology, Vol. 18, No. 3, pp. 466-476.

[4] TUDOR, D., I., PASTRAMA, S.D., HADAR, A. (2014). The Use of Computed Tomography and Ultrasonic Imaging for Assessment of Defects in Plates Made of a Polyesteric Resin. In: 
ENGINEERING TRANSACTIONS, Vol. 62, No.1, pp. 17-31.

[5] SAGAR, S.P. (2008). Moder ultrasonic techniques for defect detection in cast materials. In: CAFP - Special metal casting and forming processes, pp. 88-94.

[6] BRUNKE, O., HANSEN, F., STUKE, I., BUTZ, F. F. (2012). A new concept for highspeed altine and inline CT for up to 100\% mass production process control. In: 18th World Conference on Nondestructive Testing, 16-20 April 2012, Durban, South Africa.

[7] KRUTH, J.P., BARTSCHER, M., SCHMIT'T, R., CHIFFRE, L.DE, WECKENMANN, A. (2011). Computed tomography for dimensional metrology. In: CIRP Annals, Vol. 60, No. 2, pp. 821-842

[8] KRITIKOS, M. (2019). Effect of the Voxel Size on the Final Scan Accuracy in Computed Tomography. In: Proceedings of the International Symposium for Production Research 2019, pp.422431

[9] ANGERMEIER, C. HORR, A.H. (2014). An innovative use of CT method in light metals development. In: iCT Conference 2014 - www. 3dct.at. 5th Conference on Industrial Computed Tomography, pp. 149-157 Wels, Austria.

[10] KOLÍNOVÁ, M., BAKALOVA, T., VOLESKÝ, L., KEJZLAR, P., KOVAČÍČ, V. (2019). Non-destructive Evaluation of Pore Size and Structural Change in Geopolymer Composite Materials with Added Fibres. In: Manufacturing technology, Vol. 19, No. 1, pp. 7176.

[11] WILCZEK, A., DŁUGOSZ, P., HEBDA, M. (2015). Porosity Characterization of Aluminium Castings by Using Particular Non-destructive Techniques. In: J Nondestruct Eval, Vol. 34, article number 26.

[12] BROOKS, R. (2015). CT Technology Goes Beyond NDT, Approaching CMM. Foundry management and technology. In: bttps: / / www.foundrymag.com/ testing-qc/ article/ 21928653 / ct-technology-goes-beyond-ndt-approaching-cmm
[13] GLITTOROVÁ, D., TÓTH T., ŽIVČÁK, J. (2015). Analysis of inclusions by using computed tomography. In: eMetrológia a skúsobnictvo, Vol. 2, p. 4- 13 (in Slovak).

[14] KOLÍNOVÁ, M., BAKALOVA, T., VOLESKÝ, L., KEJZLAR, P., KOVAČÍČ, V. (2019). Non-destructive Evaluation of Pore Size and Structural Change in Geopolymer Composite Materials with Added Fibres. In: Manufacturing technology, Vol. 19, No. 1, pp. 7176.

[15] PETI, F., GRAMA, L. (2011) Analyze of the possible causes of porosity type deffects in aluminium high pressure diecast parts. In: Scientific buletin of the "Petru Maior" University of Targu Mures, Vol. 8 (XXV), No.1, pp. 41- 44.

[16] SINGH, K.K., PATRUDU, B.V., UPADHYAYA, R. (2014). Identification and Control of Micro porosity for Al-Alloy Wheel Castings. In: International Journal of Engineering Research \& Technology (IJERT), Vol. 3, No. 5, pp. 452-456.

[17] HURTALOVÁ, L., TILLOVÁ, E., BELAN, J., CHALUPOVÁ, M., et al. (2018). Observation on the formation of $\beta-\mathrm{Al}_{5} \mathrm{FeSi}$ phase depending on the content of $\mathrm{Fe}$ in aluminium vast alloy. In: Manufacturing Technology, Vol. 18, No. 4, pp. 611-615.

[18] HURTALOVÁ, L., TILLOVÁ, E., CHALUPOVÁ, M. (2013). The Changes of Fatigue Properties in Aluminium Cast Alloy during Solution Treatment. In: Key Engineering $\mathrm{Ma}^{-}$ terials, Vol. 592-593, pp. 433-436.

[19] THANABUMRUNGKUL, S., JUMPOL, W., CANYOOK, R., MEEMONGKOL, N., WANNASIN, J. (2019). Characterization of Microstructure and Shrinkage Porosity of a Semi-Solid Metal Slurry in Gravity Die Casting. In: Solid State Phenomena, Vol. 285, pp. 161-166.

[20] KUCHARIKOVÁ, L., TILLOVÁ, E., PASTIRČÁK, R., UHRÍČIK, M., MEDVECKÁ, D. (2019). Effect of Wall Thickness on the Quality of Casts from Secondary Aluminium Alloy. In: Manufacturing Technology, Vol. 19, No. 5, pp. 797-801. 